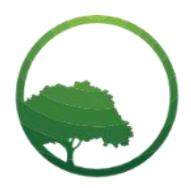

Research in Business \& Social Science

\title{
The effect of tax knowledge on relationship of procedural justice perception towards voluntary tax compliance mediated by trust
}

\author{
Rizky Rachmawan®(a), Imam Subekti@(b), Noval Adib®(c)
}

(a,b,c)Accounting Department, Faculty of Business, Brawijaya University, Malang, Indonesia

Crossref

\section{A R T ICLE INFO}

Article history:

Received 11 May 20

Received in revised form 28 May20

Accepted 30 May 20

Keywords:

Tax Compliance Procedural Justice

Trust Towards Tax Otority, Tax

Knowledge

JEL Classification:

O15, P36

\begin{abstract}
A B S T R A C T
This research aims to examine the effect of psychology factors toward voluntary tax compliance on personal taxpayers who have a business (MSME) in Malang Raya. Kirchler, Hoelzl, \& Wahl (2008) define voluntary tax compliance as the obedience based on the feeling of trust towards the tax authority. This feeling of trust towards tax authority can be created from the procedural justice obtained and felt by the taxpayers. Tax knowledge of taxpayers is also expected to strengthen the effect of perception of procedural justice towards voluntary tax compliance and the trust towards the tax authority. The researcher employed samples of personal taxpayers who have a business (MSME) in Malang Raya through a convenience sampling method. The samples of this research were 405 respondents and were analyzed by using the SEM-PLS method with WarpPLS 6.0. The research results show that procedural justice perception affects the trust towards the authority and voluntary tax compliance, the trust towards the authority also mediates the effect of procedural justice perception towards voluntary tax compliance, but tax knowledge is not proven of strengthening procedural justice perception towards the trust towards the authority and voluntary tax compliance. The result indicates that to increase tax compliance the authority must make sure the fair procedure according to taxpayers. The fair procedure will establish trust in the authority and make taxpayers easier to comply. Tax knowledge doesn't make the effect stronger because taxpayers only judge to comply according to the easy and simple procedure of tax system.
\end{abstract}

(C) 2020 by the authors. Licensee SSBFNET, Istanbul, Turkey. This article is an open access article distributed under the terms and conditions of the Creative Commons Attribution (CC BY) license (http://creativecommons.org/licenses/by/4.0/).

\section{Introduction}

Taxes is the largest revenue sector for Indonesia. The government is mandated by the 1945 Constitution to be able to collect taxes. Indonesia uses a self assessment system to collect taxes. Self assesment requires active contributions from the community to obey and comply with tax regulations. The micro small and medium enterprise (MSME) is an important part in Indonesia economi with its contribution in (Gross Domestic Product) GDP at 61,4\%. Government rule number 232018 as known PP 232018 as a legal basis and legal certainty to collect taxes for MSME to support Indonesia tax revenue. The rule can be applied well only if the tax payers have a good compliance. Tax compliance is influenced by several things, which are the inspection and fine policies, expecting that taxpayers will comply (Kirchler et al., 2008).

The main problem in collection with the self assessment system is related to tax compliance. The level of tax compliance can be seen from tax ratio. Indonesia's Tax ratio is considered low which is 10,7\%, among several ASEAN countries, such as Thailand which is $16,5 \%$, Malaysia which is $14,3 \%$, and Philippine which is $13,6 \%$ (Kurniawan et al., 2018). Another justification that can be used for assessing low tax compliance in Indonesia is the policy called Tax Amnesty. Tax amnesty is a policy to to waive unpaid tax debts by paying a certain amount of ransom. This policy is applied in Indonesai in 2016 and collect a total of 4.884 billion rupiahs ransom. Tax Amnesty policy is considered to be conducted well, however, the success of this policy illustrates that there are actually very few taxpayers who are compliant in meeting their tax obligations.

* Corresponding author. ORCID ID: 0000-0001-6539-6016

(C) 2020 by the authors. Hosting by SSBFNET. Peer review under responsibility of Center for Strategic Studies in Business and Finance. https://doi.org/10.20525/ijrbs.v9i4.725 
According to previous researchs compliance in Indonesia is based on enforced. Enforced tax compliance isnot effective in collecting taxes in a long term (Kirchler et al., 2008; Ratmono, 2014). Tax authority needs to build compliance based on trust or volunteer. Kirchler (2008) and Lind (2001) show in their research that taxpayers have to obtained a fair procedure tax collection to establish their trust through tax authority. Trust will guide them to comply by themselves. Besides trust and fairness, there must be also a knowledge that tax payers know about taxes itself that make them try to comply and paying the taxes. Taxpayers have to be able and have good knowledge about taxes and procedures that should be conducted in accordance with applicable regulations. This research adds the tax knowledge variable as a moderation variable in relation between the procedural fairness, trust in tax authorities and voluntary tax compliance. The right knowledge and understanding of tax will strengthen the relation of procedural fairness to tax trust and compliance.

\section{Literature Review}

Tax compliance is one of the problem in tax collecting system. Several theories that are used to explain tax compliance such as slippery slope theory, heuristic fairness theory explain us that tax compliance can be formed from some factors such as deterrence factors and psycological factors (Kirchler et al., 2008; Lind, 2001).

\section{Procedural Justice Perception and Trust}

Slippery slope theory by Kirchler (2008) shows us the relationship between taxpayers and tax authority. Trust toward authority means taxpayers believe that the authority will cooperate for the taxpayers benefit and willnot take advantage of them (Bornman, 2015). The trust of the taxpayers come from a fair procedure they obtained. When the taxpayers perceived that the authority has done a fair procedure, they will think that the authority can be trusted (Gobena \& Dijke, 2016). According to the heuristic fairness theory by Lind (2001) it will stimulate a willingnes to obey the tax rule. Research by (Faizal, Palil, Maelah, \& Ramli, 2017) shows that perception of justice positively correlated with trust. The result indicates how tax authority treat tax payers. Their treatment will establish tax payers behavior. Tax authority will be trusted by tax payers if they treat tax payers nicely and fairly in performing tax procedure. Based on the explanation, the hypothesis is:

H1: Procedural justice perception has a positive effect on trust in authority

\section{Trust in Tax Authority and Voluntary Tax Compliance}

Trust is one factor to establish compliance in slippery slope theory. The main idea of this concept is the cooperation between tax authority and tax payers. Tax authority does service for taxpayers' obligation, so taxpayers can support the country through payig taxes using procedure that is made. The trust that the taxpayer has for the tax authority means that the tax authority performs collecting taxes for the common good (Khasanah, Sutrisno, \& Mardiati, 2019). The finding by Bornman (2015) and Damayanti \& Martono (2018) indicates that trust toward tax authority is positively related to tax compliance. According to slippery slope theory by Kirchler et al (2008) explain when the authority is weak, trust can establish voluntary tax compliance. Increasing more trust will increase voluntary compliance from the tax payers. Based on the explanation, the hypothesis is:

H2: Trust in tax authority has positive effect on voluntary tax compliance

\section{Procedural Justice Perception and Voluntary Tax Compliance}

Heuristic fairness theory is a theory that explains the realization that almost all social and environmental relations are characterized by what is called an underlying social dilemma (Lind, 2001). Heuristic fairness theory in taxation field explained that it should be a tendency of taxpayers to be obedient in carrying out their tax obligation, when the taxpayers see it that the tax authority treats all taxpayers fairly. Procedural justice is defined as perceived fairness of procedure obtained by tax payers (Gobena \& Dijke, 2016) (Güzel, Özer, \& Özcan, 2019).

\section{H3: Procedural justice perception has positive effect on Voluntary tax compliance}

\section{Trust as Mediator Effect on Procedural Justice Perception on Voluntary Tax Compliance}

Voluntary tax compliance is formed from the high trust of tax payers (Damayanti \& Martono, 2018; Faizal et al., 2017). Trust indicates the justice level of tax authority (Konovsky \& Pugh, 1994). The relation between procedural justice and trus can be explained by heuristic fairness theory by Lind (2001). Taxpayers use fairness judgment to make a decision whether they contribute to pay taxes. Research by Gobena \& Dijke (2016) shows that voluntary tax compliance happened when they have a fair procedural in collecting taxes. Procedural justice was associated with voluntary tax compliance in low legitimate power of authority. Based on the explanation, the hypothesis is:

H4: Procedural justice perception has positive effect on Voluntary tax compliance mediated by trust

\section{Tax Knowledge and Tax Compliance}

Tax knowledge is positively related to tax compliance. Several researchs have found that tax knowledge is an important factor that can affect tax compliance. Eriksen \& Fallan (1996) in research experiment found that increasing in tax knowledge made tax payers consider their tax evasion. Palil, Akir, \& Ahmad (2013) in their research found that compliance are higher in tax payers who had 
higher education and knowledge towards tax. Tax payers with a well understanding of taxes will have more compliance (Kirchler et al., 2008). Based on the explanation, the hypothesis are:

H5: The positive relationship between procedural justice perception towards trust is moderated by tax knowledge moderated

H6: The positive relationship between procedural justice perception and voluntary tax compliance is moderated by tax knowledge

\section{Research and Methodology}

The method used in this study was a quantitative method that was used to examine a population or sample by collecting data using questionaires. The population in this study is individual taxpayers who have a personal business (MSMEs), which was included in East Java Tax Directorate General III especially Malang Raya area. The total population in the study was 31,383 people. Sample is choosed because contribution revenue of MSME in Malang Raya is very dominant. The tax revenue target have been covered, it indicates that the tax authority have a good policy to establish compliance from the tax payers.

The number of samples used was calculated using the Slovin formula:

$$
n=\frac{\mathrm{N}}{\left(1+\mathrm{N} e^{2}\right)}
$$

Description:

$\mathrm{n}=$ total samples,

$\mathrm{N}=$ total population,

$\mathrm{e}=$ error tolerance limit $(5 \%)$

The total sample obtained based on calculations with the Slovin formula was 395 respondents and this research used 405 respondents. Convenience sampling used to collect the data, where the researcher give questionnaires for taxpayers that were met by researchers directly and through a group of entrepreneurs by giving questionnaires online. The scale used in this research is a Likert scale, 1-7 score is used to the answer of the question in questionnaire for variable perception of procedural justice, trust towards authority, and voluntary tax compliance, namely Strongly Disagree (STS): 1; Disagree (TS): 2; Little bit Disagree (ATS): 3; Neutral (N): 4; Little bit Agree (AS): 5; Agree (S): 6; Strongly Agree (SS): 7. The tax knowledge variable is using only 1-3 score, 1: the answer is wrong; 2: do not know the answer; 3: the answer is true.

\section{Data Analysis Technique}

Data analysis includes validity and reliability test, and formatif construct test. Validity and reliability test are used for reflective construct. Formatif construct will be tested with different ways. Formatif construct mustnot have Variance Inflation Factor (VIF) more than 3,3 (Joseph F. Hair, Hult, Ringle, \& Sarstedt, 2014). Validity test consist of test, first convergent validity which is tested by looking the value of AVE (Average Variance Extracted) and loading factor. The loading factor must have value more than 0,4 and AVE must have more than 0,5. Second, discriminant validity, by comparing the value of loading factor and its cross loading. The value of loading factor must be higher than its cross loading. The value of reliability is tested by looking the value of cronbach alpha. The value must be higher than 0,6 (Sholihin \& Ratmono, 2013).

The hypothesis will be analysed using SEM (Structural Equation Modelling) method with WarPLS 6.0. Furthermore, Joseph F. Hair, Hult, Ringle, \& Sarstedt (2014) explain that SEM-PLS is more suited to the research that explains and predicts the construct in research.

\section{Result and Discussion}

\section{Demographic}

Total respondent obtained from the slovin formula is 395 respondents. The respondent used in this research is 405 as shown in figure 1 below:

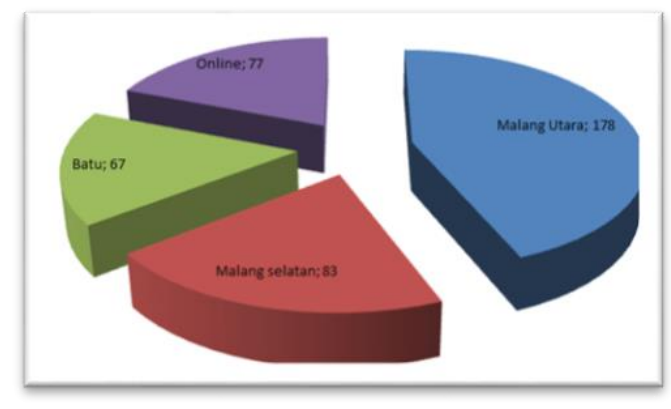

Figure 1: Respondents' count by place $(\mathrm{N}=405)$ 
Total 328 respondents obtained from different place, 178 respondents from Malang utara, 83 respondents from Malang selatan, and 67 respondents from Batu. The total 77 respondents obtained through online questioner that is sent in business community araound Malang City.

Below is the result of validity and reliability test from the variable of procedural justice perception, trust towards authority, and voluntary tax compliance:

Table 1: Validity and Reliability Test

\begin{tabular}{|c|c|c|c|c|c|c|}
\hline & PJP & TTA & VTC & TK & AVE & Cronbach's alpha \\
\hline PJP1 & $(0.774)$ & -0.234 & 0.064 & -0.012 & \multirow[t]{5}{*}{0,577} & \multirow[t]{5}{*}{0,841} \\
\hline PJP2 & (0.699) & 0.034 & -0.116 & 0,139 & & \\
\hline PJP3 & $(0.871)$ & -0.060 & 0.014 & -0.002 & & \\
\hline PJP4 & $(0.773)$ & 0.163 & 0.028 & 0.040 & & \\
\hline PJP5 & $(0.790)$ & 0.106 & -0.002 & -0.149 & & \\
\hline TTA1 & 0.194 & $(0.807)$ & -0.085 & -0.016 & \multirow[t]{6}{*}{0,632} & \multirow[t]{6}{*}{0,911} \\
\hline TTA2 & 0.155 & $(0.854)$ & -0.050 & -0.029 & & \\
\hline TTA3 & 0.180 & $(0.826)$ & -0.048 & 0.043 & & \\
\hline TTA4 & -0.254 & $(0.753)$ & 0.112 & -0.122 & & \\
\hline TTA5 & -0.236 & $(0.803)$ & 0.014 & 0.021 & & \\
\hline TTA6 & -0.080 & $(0.721)$ & 0.078 & 0.108 & & \\
\hline VTC1 & 0.151 & -0.153 & $(0.756)$ & -0.015 & \multirow[t]{10}{*}{0,585} & \multirow[t]{10}{*}{0,933} \\
\hline VTC2 & 0,176 & $-0,225$ & $(0,684)$ & 0,071 & & \\
\hline VTC3 & 0.039 & -0.006 & $(0.860)$ & -0.077 & & \\
\hline VTC4 & $-0,002$ & 0.077 & $(0.731)$ & 0.020 & & \\
\hline VTC5 & -0.036 & 0.151 & $(0.779)$ & -0.007 & & \\
\hline VTC6 & -0.128 & 0.120 & $(0.721)$ & 0.066 & & \\
\hline VTC7 & -0.170 & 0.121 & $(0.815)$ & -0.008 & & \\
\hline VTC8 & 0.101 & -0.075 & $(0.777)$ & -0.052 & & \\
\hline VTC9 & -0.046 & -0.028 & $(0.666)$ & 0.102 & & \\
\hline VTC10 & -0.067 & -0.009 & $(0.839)$ & -0.059 & & \\
\hline
\end{tabular}

Source: Primary Data, 2020

Note: Procedure Justice Perception ( PJP); Trust Towards Authority ( TTA); Volunteer Tax Compliance ( VTC)

Based on result on the table 1, it shows that all indicators for each variables have loading factor score $>0,4$ and AVE $>0,5$. Table 1 shows that all indicators for each variables have loading factor score $>0,4$ than its cross loading. The result shows that all cronbach's alpha $>0,6$, from table 1 above, it declares the data are valid and reliable.

Indicator weight and VIF (Variance Inflation Factor). Below is the result:

Tabel 2: Indicator weight Score

\begin{tabular}{|c|c|c|c|c|}
\hline Variabel & Indicators & Indicator weight & $\mathrm{P}$ value & VIF \\
\hline \multirow[t]{12}{*}{ Tax Knowledge } & TK 1 & 0,165 & $<0,001$ & 1,160 \\
\hline & TK 2 & $-0,179$ & $<0,001$ & 1,258 \\
\hline & TK 3 & $-0,170$ & $<0,001$ & 1,249 \\
\hline & TK 5 & $-0,117$ & 0,009 & 1,067 \\
\hline & TK 6 & 0,112 & 0,011 & 1,215 \\
\hline & TK 7 & 0,149 & 0,001 & 1,370 \\
\hline & TK 8 & 0,108 & 0,013 & 1,214 \\
\hline & TK 9 & 0,218 & $<0,001$ & 1,293 \\
\hline & TK 10 & $-0,235$ & $<0,001$ & 1,378 \\
\hline & TK 11 & $-0,156$ & $<0,001$ & 1,176 \\
\hline & TK 12 & 0,230 & $<0,001$ & 1,397 \\
\hline & TK 13 & 0,244 & $<0,001$ & 1,431 \\
\hline
\end{tabular}

Source: Primary Data, 2020

Note: Tax Knowledge( TK)

Based on table 2 above, all indicators have score $\mathrm{VIF}<3,3$. All indicators are suit and can be used as indicator that form tax knowledge variable.

\section{Inner Model}

Below is the result of $\mathrm{R}$ square before and after moderated. 
Tabel 3: R square Score

\begin{tabular}{lll}
\hline & R-SQUARED & \\
\hline & Before & After \\
\hline TTA & 0,573 & 0,574 \\
\hline VTC & 0,403 & 0,403 \\
\hline
\end{tabular}

Source: Primary Data, 2020

Note: Trust Towards Authority ( TTA); Volunteer Tax Compliance ( VTC)

The result of the table above shows that trust towards authority as exogenous variable is described by endogenous variable $57,3 \%$ before moderated by tax knowledge, while the remaining is affected by other factors beyond the scope of this research. Voluntary tax compliance is described by exogenous variable $40,3 \%$ before moderated, while the remaining is affected by other factors.

\section{Hypothesis Testing}

The test will be performed in two stages. First, the test is used to see the direct effect between variable exogenous and endogenous, and the second, it is used to see the mediation and moderation effect. The result of the hypothesis test are presented below:

\section{Direct Effect Testing}

The following is the direct test result on the research:

Table 4: Hypothesis Test Result

\begin{tabular}{llll}
\hline Description & Coefficient Value & P Value & Conclusion \\
\hline PJP $->$ TTA & 0,757 & $<0,001$ & Supported \\
\hline TTA $->$ VTC & 0,499 & $<0,001$ & Supported \\
\hline PJP $->$ VTC & 0,122 & 0,006 & Supported \\
\hline
\end{tabular}

Source: Primary Data, 2020

Note: Procedure Justice Perception ( PJP); Trust Towards Authority (TTA); Volunteer Tax Compliance ( VTC)

According to the hypothesis test table above, it can be seen the effect of exogenous latent variables on endogenous latent variables. Each variable has $p$ value of $<0,05$ which means some of the research hypotheses are supported. The result of the first hypothesis shows that procedural justice perception affects trust in authority. The results are relevant with heuristic fairness theory by Lind (Lind, 2001). Judgment justice is needed by tax payers so they know and believe that the authority does not gain benefit from tax collecting procedure they have. These results also support previous studies (Djajanti, Sutrisno, Subekti, \& Nurkholis, 2019; Faizal et al., 2017; Gberegbe, idornigie, \& Davies, 2015; Khasanah et al., 2019).

The result of second hypothesis shows coefficient value $0,499(\mathrm{p}<0,001)$. It means that trust toward authority affects voluntary tax compliance. Trust as a main factor to create voluntary compliance is supporting previous research (Kirchler et al., 2008; Kogler et al., 2013a). The result is aslso supporting the slippery slope theory by kirchler (2008). Compliance based on trust describes cooperative relationship between tax payers and authority. Tax payers think that the authority doing their job to collect taxes without any indication to get benefit from it.

The third hypothesis shows the result of procedural justice perception affects voluntary tax compliance with coefficient value 0,757 ( $p<0,001)$. Authority must establish a fair collecting tax procedure. A fair procedure perceived tax payers will hep them to finish their obligation well and increase theor compliance. This result supports heuristic fairness theory that tax payers use fairness to judge to comply (Khasanah et al., 2019; Lind, 2001).

\section{Mediation Effect Testing}

The mediation effect test is carried out in two steps: estimating the direct effect of the procedural justice perception (exogenous variable) on voluntary compliance (endogenous variable). Second, researcher estimates the indirect effect simultaneously. Estimation results are presented in table 5 as follows:

Table 5: Coefficient and probability value

\begin{tabular}{lcc}
\hline PJP -> VTC & Coefficient Value & Probability \\
\hline Direct effect & 0,129 & 0,004 \\
\hline Indirect effect & 0,370 & $<0,001$ \\
\hline
\end{tabular}

Source: Primary Data, 2020

Note: Procedure Justice Perception ( PJP); Trust Towards Authority ( TTA) 
Mediation test result is used to see the mediation effect in the model. Based on the table, it can be seen that the effect of the procedural justice perception on voluntary compliance is through trust towards authority as mediation variables. The direct effect coefficient value is equal to 0,129 and significant, and the value of the indirect effect coefficient is 0,370 with the significance of $<0,001$. The value of the coefficient of procedural justice perception becomes stronger when through mediation variables.

The result support the relevant theory, heuristic fairness. Tax payers uses the fair procedure perceived according to them to judge whether they want to contribute in the taxing system or not. Tax payers that believe in authority, that authorities do their job to service the country and tax payers, will have trust and they will comply as their obedient. The result support some previous research such as: Djajanti (2019), Gobena \& Dijke (2016).

\section{Moderation Effect Testing}

Moderation effect testing is performed using two phases. First phase is to find out the direct effect exogenous towards endogenous variable. Second phase is to find out the moderation effect itself. The following table is the result of hypothesis testing for the moderation effect in this research:

Table 6: Phase 1 Test Result

\begin{tabular}{lll}
\hline Description & Coefficient Value & P Value \\
\hline PJP $->$ VTC & 0,122 & $<0,001$ \\
\hline TK $->$ VTC & 0,293 & $<0,001$ \\
\hline PJP $>$ TTA & 0,757 & $<0,001$ \\
\hline TK $->$ TTA & 0,256 & $<0,001$ \\
\hline
\end{tabular}

Source: Primary Data, 2020

Note: Procedure Justice Perception ( PJP); Trust Towards Authority ( TTA); Volunteer Tax Compliance ( VTC)

The first phase testing result as presented in table 6 shows that the interaction between moderator variables on endogenous variables is significant. This indicates that the moderator variable of tax knowledge probably has a moderation effect on the relation between the procedural justice perception on trust in tax authorities and voluntary tax compliance.

The result of moderation effect is presented below:

Table 7: Phase 2 Test Result

\begin{tabular}{llll}
\hline Description & Coefficient Value & P Value & Conclusion \\
\hline TK*PJP -> TTA & $-0,041$ & 0,203 & Rejected \\
\hline TK*PJP -> VTC & $-0,073$ & 0,069 & Rejected \\
\hline
\end{tabular}

Source: Primary Data, 2020

Note: Procedure Justice Perception ( PJP); Trust Towards Authority ( TTA); Volunteer Tax Compliance ( VTC)

Table 7 shows the moderation effect of tax knowledge on the relation between procedural justice perception towrds trust in tax authorities. The testing result shows that there arenot significant value for moderation effect of tax knowledge between procedural justice towards trust is authority and procedural justice towards voluntary tax compliance repeatedly (p 0,203 > 0,05 and p 0,269> 0,05). This result proves that hypothesis arenot supported. Tax knowledge doesnot moderate the relation between the procedural justice perception towards trust in tax authorities and procedural justice perception towards voluntary tax compliance. According to table 6 and 7 , it can be seen that the type of moderation variable that appears is homologiser moderator, which means that the potentially tax knowledge variable become a predictor for the voluntary tax compliance variable but not a moderation variable.

A Better tax knowledge will lead tax payers become more compliance through trust in authority (Kirchler et al., 2008). Tax knowledge dosenot make the relationship between procedural justice perception and trust, procedural justice perception and voluntary tax compliance, become stronger. The judgement used by tax payers to understand the fair procedure are not from their knowledge about the goal of the tax and the benefit they get if they pay tax, but from the procedure they perceived, whether it is complicated or not.

Saad (2014) in his research shows that the complexity of the tax law as contributing factors towards on noncompliance. The newest rule for MSME in Indonesia as known as PP 232018 makes them to obedient become easier and more simple. The tax payers are demand to do their obligation well and obey the rule. According to them the simple and not complex procedures are more fair for them and finally leads to have more trust and comply. 


\section{Conclusions}

This research concludes several matters. Procedural justice perception and trust in authority have a significant effect and positively related to voluntary tax compliance. In addition, Trust in authority mediates the relationship of procedural justice perception on voluntary tax compliance. The last, tax knowledge does not moderate the relationship between procedural justice perception on voluntary tax compliance and the relationship of procedural justice perception on trust in authority.

The results indicate that the MSMe tax payers are judging the fairness procedure from the complexcity. Especially, for MSMe tax payers in Malang City, they need to pay tax in simple way, they do not have to make a report every month. The different way is used for the other kinds of tax payers. The results are expected to contribute the government as the law maker to make sure the the procedure to collect the tax using fair procedur for the MSMe tax payers.

Recommendations for the future research are in this research we use only one kind of fairness. Future research can add more such as distributive justice and retributive justice. Tax knowledge variable used in this research consists of 13 indicators, for the future research can make it more simple and devide them into a few dimension.

\section{References}

Bornman, M. (2015). The determinants and measurement of trust in tax authorities as a factor influencing tax compliance behaviour. Journal of Economic and Financial Sciences, 8(3), 772-789. doi:10.4102/jef.v8i3.121

Damayanti, T. W., \& Martono, S. (2018). Taxpayer Compliance, Trust, and Power. Jurnal Keuangan dan Perbankan, 22(2), 231239. https://doi.org/10.26905/jkdp.v22i2.1580

Djajanti, A., Sutrisno, Subekti, I., \& Nurkholis. (2019). The Role of the Power of Tax Authority in Voluntary Tax Compliance. The Case Study of Jakarta, Indonesia Journal of Applied Economic Science, 63(1), 73. https://doi.org/10.26905/jkdp.v22i2.1580

Eriksen, K., \& Fallan, L. (1996). Tax knowledge and attitudes towards taxation: A report on a quasi-experiment. Journal of Economic Psychology, 17, 387-402. https://doi.org/10.1016/0167-4870(96)00015-3

Faizal, S. M., Palil, M. R., Maelah, R., \& Ramli, R. (2017). Perception on justice, trust and tax compliance behavior in Malaysia. Kasetsart Journal of Social Sciences, 38, 226-232. doi:http://dx.doi.org/10.1016/j.kjss.2016.10.003

Gberegbe, F. B., idornigie, G. A., \& Davies, L. O. N. (2015). Perception of Tax Fairness and Personal Income Tax Compliance in Ken Saro-Wiwa Polytechnic, Bori. Journal of Economics and Finance, 6(6), 1-11. http://doi.org/10.9790/5933-06610111

Gobena, L. B., \& Dijke, M. V. (2016). Power, Justice, and Trust: A Moderated Mediation Analysis of Tax Compliance among Ethiopian Business Owners. Journal of Economic Psychology, 52, 24-37. doi:http://dx.doi.org/10.1016/j.joep.2015.11.004

Güzel, S. A., Özer, G., \& Özcan, M. (2019). The effect of the variables of tax justice perception and trust in government on tax compliance: The case of Turkey. Journal of Behavioral and Experimental Economics, 78, 80-86. https://doi.org/10.1016/j.socec.2018.12.006

Joseph F. Hair, J., Hult, G. T. M., Ringle, C. M., \& Sarstedt, M. (2014). A Primer on Partial Least Squares Structural Equation Modeling (PLS-SEM). Los Angeles: SAGE Publications.

Khasanah, U., Sutrisno, \& Mardiati, E. (2019). Coercive Authority and Trust in Tax Authority in Influencing Voluntary Tax Compliance: A Study of Slippery Slope Journal of Accounting and Investment, 20(1), 75-93. https://doi.org/10.18196/jai.2001109

Kirchler, E., Hoelzl, E., \& Wahl, I. (2008). Enforced versus voluntary tax compliance: The "slippery slope” framework. Journal of Economic Psychology, 29, 210-225. https://doi.org/10.1016/j.joep.2007.05.004

Kogler, C., Batrancea, L., Nichita, A., Pantya, J., Belianin, A., \& Kirchler, E. (2013a). Trust and power as determinants of tax compliance: Testing the assumptions of the slippery slope framework in Austria, Hungary, Romania and Russia. Journal of Economic Psychology, 34, 169-180. https://doi.org/10.1016/j.joep.2012.09.010

Konovsky, M. A., \& Pugh, S. D. (1994). Citizenship Behavior and Social Exchange. Academy of Management Journal, 37(3), 656669. . https://doi.org/10.2307/256704

Kurniawan, R., Amir, H., Kusumawardani, P. P. O., Suryono, N. D., Effendi, R., Purwitohadi, . . Abdillah. (2018). Tax Expenditure Report 2016-2017. Jakarta Badan Kebijakan Fiskal Kementerian Keuangan

Lind, E. A. (2001). Fairness Heuristic Theory: Justice judgements as pivotal cognitions in organizational justice.

Palil, M. R., Akir, M. R. M., \& Ahmad, W. F. B. W. (2013). The Perception of Tax Payers on Tax Knowledge and Tax Education with Level of Tax Compliance: A Study the Influences of Religiosity. ASEAN Journal of Economics.

Ratmono, D. (2014). Model kepatuhan perpajakan sukarela: peran denda, keadilan prosedural, dan kepercayaan terhadap otoritas pajak. Jurnal Akuntansi dan Auditing Indonesia, 18(1), 42-64.

Saad, N. (2014). Tax Knowledge, Tax Complexity and Tax Compliance: Taxpayers' View. Social and Behavioral Sciences, 109, 1069-1075. https://doi.org/10.1016/j.sbspro.2013.12.590

Sholihin, M., \& Ratmono, D. (2013). Analisis SEM-PLS dengan WarpPLS 3.0 Untuk hubungan non linier dalam penelitian sosial dan bisnis. Yogyakarta: ANDI Yogyakarta. 